\title{
NON-TRADITIONAL SECURITY THREATS IN THE BORDER AREAS: TERRORISM, PIRACY, ENVIRONMENTAL DEGRADATION IN SOUTHEAST ASIAN MARITIME DOMAIN
}

\author{
E.L. Dabova \\ Department of international law, School of Law, Saint Petersburg State University, 22nd line Vasilevskii ostrov, Saint Petersburg \\ 199026, Russia - lenadabovasbpgu@ gmail.com
}

KEY WORDS: Non-traditional security, Southeast Asia, Maritime domain, Bordering areas, International law, Regional cooperation

\begin{abstract}
:
In addition to facilitating peaceful trade and economic development, sovereign territory, territorial waters and international waters are being used by various criminal groups that pose threats to governments, businesses and civilian population in Southeast Asia. Nonstate criminal maritime activities were not receiving appropriate attention as they were overshadowed by traditional military security challenges. Yet more and more frequently, the non-traditional actors challenge lines of communication, jeopardize access to strategic resources, complicate traditional defence tasks, and harm the environment. Understanding the nature of non-traditional threats, and the ways to combat them, requires international legal, historical and political science analysis within a united problem-oriented approach. A fair critique to pure interest, power and knowledge -based theories of regime formation was developed by E.K. Leonard's ${ }^{1}$, who explained the evolution of the international system from the global governance perspective. The present study is based on the premise that pure nation-state approaches are incapable of providing a theoretical ground for addressing the growing influence of international criminal networks in South East Asia. From an international relations theory perspective, the author of this study agrees with D.Snidal ${ }^{2}$ that the hegemonic stability theory has "limits" and is insufficient in describing modern challenges to sustainable international security regime, including non-traditional threats, where collective action is more efficient from an interest and capability standpoint. At the same time the author of this study does not share the viewpoint on "marginalization" 3 of international law in current international order

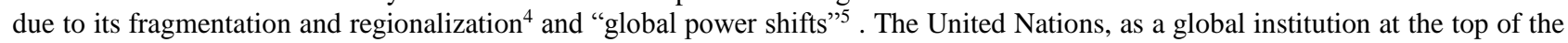
vertical hierarchy of international legal order, and the EU as an example of "self-contained" regime along with other subsystems like South East Asia may have different approaches to global governance, international constitutional order, or particular cases such as the measure of infringement of human rights when targeting individuals suspected of terrorist links. Yet international law remains the key part of the Asian and global security regime. The hypothesis of this study is that the "void of governance" regime in territorial and international waters provides lucrative environment for developing terrorism, piracy, environmental degradation, and other criminal activities that pose untraditional threats to the regional security. This "void of governance" regime can be caused by either, or both, de jure or de facto insufficient control over particular marine territories.
\end{abstract}

\section{PUBLIC LAW ASPECTS OF "VOID OF GOVERNANCE REGIME"}

\subsection{Boundaries disputes}

Almost all South East Asian countries claim islands and waters in the sea. Those unestablished maritime boundaries6 is a serious challenge to stable and effective security regime. They create confusion in terms of rights of use and responsibilities to protect and can erupt in violence from the aggressive claimant or a third party, such as terrorists or pirates. Straits and islands, for example, being the smallest geographical part of a vast regional maritime domain, are a big defence challenge for national navies. While, the total area of disputed Spratley islands themselves is less than 3 square miles, each small island allows the sovereign owner to claim the surrounding waters as an exclusive economic zone (EEZ) which under the $\mathrm{UNCLOS}^{7}$ extends to $200 \mathrm{~nm}$ from the coastline. At the same time straits as the bottlenecks on the

\footnotetext{
${ }^{1}$ Leonard, E.K., 2005

${ }^{2}$ Snidal, D., 1985

${ }^{3}$ Pareja-Alcaraz, P.,2009

${ }^{4}$ Draghici C., 2009

${ }^{5}$ Hoge, J., 2004

${ }^{6}$ UNCLOS recognizes maritime boundaries such as territorial waters, contiguous zones, and exclusive economic zones but does not include lakes or rivers, while multilateral treaties describe the baselines of countries. Islands and submerged seabeds of the continental shelf affect maritime boundaries. The limits of maritime boundaries are expressed in polylines and in polygon layers of sovereignty and control, calculated from the declaration of a baseline under conditions described in UNCLOS. The zones of maritime boundaries are expressed in concentric limits surrounding coastal and feature baselines. Internal waters, territorial waters and exclusive economic zone can be contrasted with international waters or trans-boundary waters that include oceans, seas, and waters outside of national jurisdiction -the high seas or, mare liberum (free seas). Ships are generally under the jurisdiction of a state but if the ship is involved in certain criminal acts, such as piracy, any nation can exercise jurisdiction under the doctrine of universal jurisdiction, which allows states or international organizations to claim jurisdiction over an accused person regardless of where the alleged crime was committed, and regardless of the accused's relation with the prosecuting entity.

${ }^{7}$ United Nations Convention on the law of the sea, November 16th, 1994
} 


\section{5 - 6 December 2013, Beijing, China}

trading routs proved to be extremely vulnerable to such a threat as a blockade. In the 20th century, East Asia saw seven naval blockades. The "classic example of modern limited blockade" during the Falkland Islands war of 1982 showed that blockades of a strait that is a vital trading route does not require massive military capabilities and potentially can be conducted by nonstate actors. Today, the Southeast Asia region has islands/straits disputes, including the North Borneo (Sabah) territory between Malaysia and Philippines, Paracel islands, and Senkaku islands. Undefined boundaries between states inhibit stable legal regime of the use and protection of straits and waters around those islands. The countries in the South East region are also not keen on delegating all the territorial disputes to the ICJ. 8 Part of the reason is that that the ICJ has moved from pure geographic approach of defining borders to socio-geographic "proportionality" approach, which makes the results "pseudomathematical" and raise questions in terms of their rationality.9 The positive exclusions were Malaysia and Singapore memorandum to refer their dispute to the ICJ, which granted Pedra Blanca to Singapore, Middle Rocks to Malaysia, and South Ledge to whichever state in whose territorial waters it lies.

\subsection{Imbalance of inclusive and exclusive interests of states}

Undisputed international maritime boundaries do not guarantee efficient control over the maritime domain and are not enough to facilitate peaceful use of the waters. The understanding of common vs. unique or inclusive vs. exclusive interests of states and communities needs to change when it comes to actual control, use and protection of maritime domain.

Transnational threats can be a serious impulse for increasing international cooperation. By combining the resources and capabilities of many nations, the rigidly defined and nationally focused approach to security can be transformed into one that is flexible and cooperative. 10 The common interest in combating transnational threats to maritime security may cause some readjustment of exclusive and inclusive interests in the current laws. In terms of capabilities, no single nation in the region can exercise sovereign control over its maritime assets, resources and venues from which transnational threats endanger international security. At the same time, modern economic interest of peace and stability in commonly used maritime domain is undeniably a shared interest. Evolution in the laws of the sea does not mean abandonment of flag state control over vessels or ceasing the recognition of the coastal state sovereignty over the territorial sea. Rather it means recognizing common interests that could be better served if there were a broader allocation of competences among the interested parties, for example by simplification of some procedural rules in time sensitive operations.

${ }^{8}$ The ICJ has jurisdiction in two types of cases: (a)issues between states that agree to submit to the ruling of the court; (b) issuing advisory opinions, which provide non-binding ruling on submitted questions of international law, often times at the request of the United Nations General Assembly. Advisory opinions do not affect directly other disputes or uninvolved states, but they influence the process of decision making by setting tradition.

${ }^{9}$ Maritime boundaries decisions by ICJ are not common law in the classic sense; they are customary international law grounded on state practice, which resulted in a great diversity of boundaries settlements. The proponents of pure coastal geography approach believe that many other nongeographic considerations may slow the evolution of the law. The
The South East Asia multi-lateral cooperation in protecting maritime domain faces certain obstacles due to characteristics of the regional order developed after WWII and during the decolonization process. The constitutional structure of the regional order includes three interconnected elements- a hegemonic belief in moral objective of a centralized and autonomous political organization, the organizational principle of sovereignty, and the "consensual" norm of procedural justice. The post-colonial states were left in hands of small groups of government elites who promoted a political culture of privacy and informality. Historical distrust, reflected in various territorial disputes, also encouraged norms that required minimum level of cooperation without high levels of formality to avoid bringing state sovereignty into question. The main positive example of multi-lateral cooperation on high level during and after the Cold War was ASEAN partly because it adapted the deeply rooted tradition of personal, informal and non-contractual political relations. At the same time, the ASEAN preference for "soft" law with low legalization of the provisions formed a tradition of resorting to minimum binding legal instruments or instruments with low level of obligations. Multilateral agreements mostly in the form of declarations of principles, political commitments or guidelines have a notable degree of imprecision and vagueness especially in terms of prohibited forms of conduct. While this level of definition leaves more room for diplomatic manoeuvring in inter-states relations, this same vagueness serves as loopholes for non-state actors that use poorly defined norms against the states as a source of impunity for their transnational crimes.

On the global level, while the maritime security challenges drift more and more away from classical state-to-state conflicts, the existing international legal institutions were not designed for guiding the behaviour of new actors and limiting their range of actions to balance their rights and responsibilities, like those of nation states, for the sake of bringing more certainty into complex relations of state and non-state participants international relations. International threats such as terrorism, piracy, smuggling and other criminal activities call for appropriate international regulations that would not put all the responsibility on the states. Violence from non-state actors, whose acts are not attributable to a state11, can use traditional military capabilities, including WMDs. While international law has provided a gradation of intervention - from threats of force to use of force to armed attack - the interpretation of each military activity in the sea is still a question for decision makers who have to decide on the proportionate response. Though acts of violence of non-state actors can be as destructive as a traditional military attack, threats from non-state actors are not as easy to recognize. This recognition is essential to invoke the right of self-defence. However, the UN Security Council resists permitting wide-ranging interdictions. More appreciation for the inclusive interest of improving maritime security is needed to provide a basis for the intrusion on the freedom of navigation.

proponents of historical, conventional and other social rights warn against relying on the "uncertainties" of the geologic science that can provide only "relatively precise" delimitation of the maritime boundaries.

${ }^{10}$ Peppetti, J.D., 2008

${ }^{11}$ The Charter of the UN, articles 2(4) and 51, prohibits the threat of use of force and secures right of self-defence; the ICJ Nicaragua 1986 case determined that arming and training of the contras were violations of the prohibition on the recourse to the threat of force and principle of non-intervention; and, The Declaration on Friendly relations in accordance of UN Charter elaborated the categories of "threat of force" and "use of force". 


\section{5 - 6 December 2013, Beijing, China}

International terrorism and the proliferation of WMDs caused some political cooperation within the anti-terrorism coalition and demonstrated that security may reflect the inclusive and exclusive claims to ocean space and use. The new rules that promote inclusive interests at the expense of exclusive interests, such as sovereignty over the territorial sea and exclusive flag authority, came about through Security Council decisions and bilateral and multilateral treaties that were adopted over the past 10 years. The Security Council has recognized the significance of certain maritime security threats to international peace and can improve maritime security by exercising its Chapter VII powers. On the other hand, while the modern peacetime maritime security concerns prompted some revision of the rules of the use of force and the law of the naval warfare due to traditional military interests relating to the passage and the conduct of military activities, including intelligence gathering in another state is EEZ, they also met rightful resistance. Improvement of maritime security requires a shift from three fundamental tenets of the law of the sea: state sovereignty over the territorial sea, freedom of navigation in the EEZs and on the high seas, and the exclusive jurisdiction of the flag state over its vessels. The shift requires protecting existing interests. As a result, evolution of the law of the sea has serious obstacles in keeping pace with the socialeconomic development of the world and trade dynamic in SouthEast Asia.

\section{SOCIO-POLITICAL ASPECTS OF "VOID OF GOVERNANCE" REGIME}

Social and political factors can undermine the lawful governance of national or international waters. These factors of include (a) the social vulnerability of the local coastal population, (b) rapid economic development of the region with insufficient infrastructure, (c) historical distrust among neighbouring countries of the region.

\subsection{Social challenges of state control and political obstacles to regional institution building}

The local coastal communities of the region are full of various ethnic groups with low educational levels and economic and social autarchy. These ethnic groups are easily manipulated though the loyalty system in which their personal allegiance is determined not by citizenship but by clan or tribal interests. These interests push them to collaborate with international criminal groups rather than national or international security forces. The areas in Southeast Asia where maritime crime is most prevalent-along the coast of Sumatra bordering the Malacca Strait, and areas along the Sulu and Celebes Seas - are characterized by poor governance, at both central and local levels, weak institutions, widespread poverty, corruption, and the existence of underground economies rivalling that of the formal economy. Most people in these areas do not have access to land, property rights, or resources, and have been excluded from meaningful political participation. At the same time, numerous NGO's that are focusing on maritime crime in the region operate independently of each other. These NGOs could make a larger impact by working together with one another, and with think tanks and private foundations. NGOs can advocate for changes in the laws to accommodate economically justified activities that are currently characterized as illegal. For example, people using the barter boats to travel between Sabah and the Southern

${ }^{12}$ Marketos, T.N., 2009.
Philippines should be viewed not as smugglers but as necessary goods and passenger service.

South Pacific used to be considered as being "the edge of the map" but as the world pivots to the Asia-Pacific, the South Pacific region's true geopolitical, strategic and economic value is coming to the fore. As U.S. Pacific Command Commander Admiral Samuel Locklear said in the Cook Islands in 2012: "Five trillion dollars of commerce rides on the (Asia-Pacific) sea lanes each year." Far from being small island states, the Pacific Island Countries are showing themselves as large ocean states, with vast fisheries, potential seabed resources, and increasingly important geostrategic positioning - as the range of military bases dotted throughout the region can attest. At the same time, the region shows obvious shortage of political and economic institutions necessary to provide safe and legal infrastructure proportionate to the new scale of economic activity in Asia. The region has been traditionally relying on limited bilateral measures without concerted policy direction between countries, often times at their neighbour's expense12. This tradition holds back any multilateral defence project. Influenced by historical development of norms of common security, non-interference or nonalignment, there is also still lack of consensus on regional identity and direction of the security cooperation: "open regionalism", advocated by OPEC: "cooperative" security via ARF or "the ASEAN way". At the same time "hub-and spoke" pattern of US alliances and ASEAN style of "spider web", do not represent a multilateral solution to maritime security challenges of the region.

\subsection{Non-traditional threats}

While both state and non-state actors can challenge trading routs, the environment and maritime natural resources. Non-traditional maritime security threats are those that (a) undermine economic development and social stability, (b) cannot be contained by traditional national military capabilities/law enforcement agencies/economic sanctions and (c) are caused by non-state actors. At the top of the list of non-traditional threats to maritime security are terrorism, piracy, human, drug and arms trafficking, environmental degradation due to illegal fishing, dumping of waste and ship dismantling.

Originally, maritime terrorism was understood as piracy whereby any unauthorized act of violence on the high seas would be characterized as piracy.13 Following the terrorist attack on the United States in September 2001, it was recognized that a terrorist attack in a major port or vital shipping channel, particularly if it involves a WMD, could potentially close down international commerce for a length of time with economic repercussions, given that 90 percent of the world trade is facilitated by sea, and cause long-term environmental and social crisis. Maritime terrorism means both an act of violence, for example exploding an oil or gas vessel, or use of international shipping for personal transport, shipping supply and means of finance of terrorist activities. Since 9/11, the term has included ungovernable or ungoverned spaces, where the host government lacks physical capacity and/or political will to exercise sovereign power and terrorists conduct their operations with impunity. The South East Asia region, in particular the territory and territorial seas of three states-Philippines, Indonesia and Malaysiaconstitutes a single geopolitical space that affects the stability of the larger South East Asia maritime domain. Ties of commerce, navigation and settlements across the Celebs and Sulu seas are conducive to transnational criminal activities. These areas, being outside of central administrative control, and influenced by ethno-national, ideological and religious conflicts, allow criminal

${ }^{13}$ Halberstam, M., 1988 


\section{5 - 6 December 2013, Beijing, China}

networks to recruit and operate hidden from national law enforcement agencies and counterterrorism agencies. The TBA continues to be a key logistical corridor for the Indonesian terrorist group Jemaah Islamiyah and its offshoots; the Suluarchipelago based Abu Sayyaf Group, which conducts acts of maritime terrorism, kidnapping, piracy and other criminal activities, and the Moro Islamic Liberation Front-the largest terrorist organization in South Philippines, for arms trafficking.

Over the past two decades, piracy activities in Southeast Asia have been recognized as a serious threat to regional security. While states have played a leading role in fighting maritime piracy, anti-piracy nongovernmental organizations (NGOs) - ranging from industry and seafarer associations to think tanks and Track II scholarly networkshave also been influential in addressing this problem. Various NGOs, especially the International Maritime Bureau (IMB), have successfully portrayed piracy as a threat to navigational safety, maritime trade, energy security, and a potential source of terrorism. The pressure exerted by NGOs on littoral governments in Southeast Asia resulted in greater state-to-state and regional military cooperation, as exemplified by the 2004 landmark maritime initiative between Malaysia, Singapore, and Indonesia-MALSINDO- to patrol the Strait of Malacca. Operation MALSINDO has been successful in curbing the number of pirate attacks and industry watchers assume that the current approach is working.

While the actual number of piracy cases may be perceived as dropping, the total number of maritime crimes in the Strait of Malacca has actually increased. In particular, the smuggling of people and goods is contributing largely to the negative statistics. Each boatload of 50 to 100 undocumented migrants traveling between Malaysia and Indonesia across the Strait of Malacca, for example, earns the smuggling syndicates between US $\$ 15,000$ and US $\$ 30,000$, a high return for a relatively low risk. Unfortunately, undocumented migrants are just one commodity for smuggling syndicates. Other illegal but very profitable items include drugs, stolen motorcycles and outboard engines, cigarettes, timber, fish, sand, gravel and soil for reclamation work, not to mention maritime kidnappings for ransom. These unlawful activities along the Strait of Malacca and in the Sulu Sea--between Sabah in Northern Malaysia and the Southern Philippines are more predictable and less dangerous than maritime piracy.

The South China Sea is one of the richest fishing grounds in the world. Yet many coastal communities in Southeast Asia are dependent on illegal fishing 14 . Overfishing

${ }^{14}$ UNCLOS recognizes the freedom of fishing on the high seas, subject to conservation and management obligations. Additionally a global treaty-the Fish Stock Agreement-was signed in 1995 to allow for enforcement rights against foreignflagged vessels on the high seas when there are clear grounds for believing that a vessel has engaged in any activity contrary to conservation and management.

15 Dumping waste into the ocean was legal until the Ocean Dumping Act was passed in 1972. Within 20 years, about 25 million tons of waste including scrap metal, chemicals, and acids were dumped into the ocean, contributing to the depletion of the oxygen in the water killing marine life and poisoning the local population. Grey, Black and White lists of chemical elements are used to prevent dumping in the ocean.

${ }^{16} \mathrm{As}$ Guardian suggests in the article by environmental editor John Vidal on March 27th 2005, large quantities of Irish rubbish disguised as waste paper go to Indonesia every year, while in 2004 a study by Impel, a group of waste inspectors from six European countries, suggested that up to $20 \%$ of the tens of thousands of containers full of waste plastic and paper in the Strait of Malacca in the 1990s - exacerbated by large-scale commercial fishing and illegal fishing by foreign trawlers, especially Thai boats--depleted fish stocks, leading to dwindling incomes for local communities. This combined with political instability in West Sumatra (Indonesia) and the Southern Philippines bordering Sabah, along with a lack of other economic opportunities forced even more coastal residents to resort to various maritime crimes for survival. Different organizations, including Europol keep warning about the increase in illegal waste dumping 1516 Driven by an exceptional 'low risk - high profit' margin, illegal waste trafficking and disposal activities have become one of the fastest growing areas of organized crime. Criminals are organized into sophisticated networks with collection, transportation and legal experts who are exploiting the high costs associated with legal waste management and are making substantial profits from illegal trafficking and disposal activities, circumventing environmental legislation. The trafficking groups themselves are usually small (between 5 and 10 people), with ethnic links to the destination countries, and use intermediate storage sites to disguise the ultimate destination of waste. 17 Yet the illegal dumping is not caused by importing hazardous materials only. As Greenpeace official Vinuta Gopal believes, Asia alone is estimated to be generating 12 million tons of e-waste a year. While close to 40,000 tons of foreign used electronic equipment, find their way to India, close to $40 \%$ of the handled e-waste is generated locally. In India, there is no specific law to prevent importing e-waste, but a court order that bans import of all hazardous waste.18 Ship dismantling. Another threat to environmental security in the marine eco-systems is ship dismantling. The Hong Kong International Convention for the Safe and Environmentally Sound Recycling of Ships of 2009 was attended by delegates from 63 countries but still has to be ratified.19 The Hong Kong Convention for example addresses the fact that ships sold for scrapping may contain environmentally hazardous substances such as asbestos, heavy metals, hydrocarbons, and ozone-depleting substances. Yet there are obstacles to ratifying the convention. Once the convention comes into force, the development of Inventory of Hazardous Material (IHM) will be a significant task for ship owners. Developing and maintain this Inventory will require a massive force of experts and extra expenses, 10,000 to 30,000 dollars per vessel per year, according to the estimates mentioned at the 2nd Annual Conference of Ship Recycling on the Indian SubContinent in Mumbai held in September 2013. On the other hand, if the method that is used to recycle most of the vessels in the world-the beaching process-were banned due to environmental

are illegally sent annually from Europe for recycling to China and south-east Asia.

${ }^{17}$ In summer 2013, Greenpeace and EcoWaste Coalition tried to shut down the illegal dumpsite Pier 18 in Manila Bay that belongs to PhilEco Company after the local government failed to deal with waste dumps in Metro Manila, the facility that has also a record of harassing environmental and social justice workers. The security personal of PhilEco cut the mooring lines used to block the pier and forced their way through the blockade of Greenpeace inflatables by threatening to shoot at peaceful activists.

${ }^{18}$ India the digital dumping ground. http: //www.atimes.com/atimes/South_Asia/HH03Df01.html.( October 27th, 2013)

${ }^{19}$ The text of the Hong Kong Convention was developed with input from International Maritime Organization Member States and relevant non-governmental organizations, and in co-operation with the International Labour Organization and the Parties to the Basel Convention 


\section{5 - 6 December 2013, Beijing, China}

concerns it would lead to a massive number of abandoned ships drifting around in the oceans posing a great threat to navigation. 20

\subsection{Non-traditional threats as a naval affair}

Modern theoretical concepts were developed during the cold war to combat traditional military threats from nation states. The 21 st century global and regional security threats are international in geography and more and mostly non-state in nature. Assured and stable access to the global commons, such as maritime domains, is being undermined by new "hybrid" threats that blur the traditional categories of naval warfare, such as threats or uses of force and armed attacks.21 This situation naturally calls for the cost-efficient multi-lateral solution, but states in this region do not have full autonomy from their military, which leads to uncoordinated state behaviour, further unilateral militarization and distrust in South-East Asia maritime domain.22 Military in general and navy of the countries in the region in particular enjoy special position of pursuing their development strategy even if it diverges from the general policy of their countries. Regional security remains predominantly a "naval affair" when it is clear that even growing Chinese naval capabilities are not sufficient to defend vital straits or the Chinese "Near Seas" maritime domain, that stretches all the way to the Persian Gulf.23 On the other hand, decreasing state control can empower naval industries as power brokers, which in turn can give the national navies even more advantage for expanding their zones of control through aggressive pressure, for example, through island and maritime claims.

An alternative approach would require coordinated multi-lateral involvement of traditional naval capabilities along with other national law-enforcement agencies in order to increase the enforcement powers of the coastal states. The recent example of CWS (Coastal watch system) initiative aims to overcome the failures of the unilateral naval approach, such as lack of awareness of the complex nature of the modern nontraditional threats to the maritime domains, lack of addressing the social issues that are driving population to engage into illegal maritime activities24i, and lack of integrated institutional approach. The CWS was first conceptualized in 2006 and came into being in 2008 to boost maritime surveillance in the TBA. It was intended to be an interagency effort involving the Philippine navy, national police, coast guard, intelligence agency, antiterrorism task force, fishery, customs, immigration, health services and maritime industry authorities to establish the system of maritime domain awareness and later link with similar initiatives in Malaysia and Indonesia to create a sub-regional regime of MDA (Bakorkamla) that could be then tied into broader Asia-Pacific multi-lateral arrangements such as the Information Fusion centre in Singapore. The whole system is coordinated by the Maritime research information centre in Manila, which operates 24/7 and has a staff of four naval and eight enlisted personal and six civilian employees. The MRIC is primarily responsible for compiling strategic threat assessment, which provides a unified picture of the maritime environment. Actual executive authority for initiating action against a suspected threat lies with senior naval officer in each of the four

${ }^{20}$ This method is practiced in India, Bangladesh and Pakistan, who recycle the lion share of world's vessels. None of these countries is ready to ratify the Hong Kong Convention.

${ }^{21}$ Hybrid threats employ a mix of conventional weapons, irregular tactics, WMD, cyber-attack, supported by information campaign, while non-state actors are employing a blend of components of the spectrum of conflict in economic, diplomatic, informational or social domains.
CWS stations-West Palawan, Luzon, Mindanao, Davao city. Each facility has local fusion hubs for offshore radar platforms that fall within their jurisdiction; Automated Information System, UHF-band radios, high-powered binoculars and infrared color cameras. The CWS will eventually consist of 20 offshore platforms that will have both surveillance and interdiction capabilities. By 2012, 12 were operational, two in the final stages of development, and three remained a work in progress. CWS owns light patrol gunboats and fixed wing Islander aircrafts and additionally can draw assets from $\mathrm{PN}$ on an as-needed basis. The main benefit of CWS is that it provides relatively cheap system surveillance of a large expanse of maritime territory and assistance of other initiatives such as the Maritime Group for enforcing maritime law and saving lives and promotion of confidence building in the three littoral states. On the downside, the CWS lacks aviation and surveillance equipment and personnel while the Philippine navy faces problems maintaining its old-generation craft. From a regional standpoint, while Manila has entered into a number of standing cooperative maritime arrangements with Kuala Lumpur and Jakarta, there has yet been no decisive move to formalize this collaboration beyond bilateral government-to-government context, which is away from desired regime of integrated regional maritime security. 25

Traditional naval approach to maritime security still dominates the region of South-East Asia. There are national and regional institutions in South East Asia but most of them do not cooperate and lack political will or economic resources to implement their uncoordinated initiatives.

\section{RECOMMENDATIONS}

Based on the premise that current efforts to combat non-traditional threats in South East Asia maritime domain face (a) conceptual and institutional weakness, (b) lack of relevant technical infrastructure, (c) lack of clear national economic regulations, (d) challenges posed to public international law by non-state actors; the author suggests the following recommendations:

First, to develop a complex concept of non-traditional threat to maritime security that would include legal, economic, military and social characteristics in the frame work of ASEAN and its human security agenda, as a step to overcoming the existing lack of regional cooperation on creating integrated regional maritime security regimes.

Second, to discuss legal characteristics of regional shared interests in maritime security in a framework of a scientific workshop. The regional legal discussion on the application of public law regulations to non-traditional security threats in South East Asia maritime domain, such topics as, nontraditional threats as armed conflicts at seas, change of legal status of non-state criminals and international "responsibility to protect"; evolution of UCLOS and the principle of freedom of navigation on high seas; possibility of involvement of UN peace-

${ }^{22}$ Erickson, A.,Collins, G. $a, 2012$

${ }^{23}$ Erickson, A.,Collins, G. $b, 2012$

${ }^{24}$ For example, military patrol is an effective short-term deterrent for piracy, but in the long-run the more important issue is not apprehending and incarcerating pirates but rather preventing coastal communities from turning to piracy in the first place.

${ }^{25}$ Rabasa, A., Chalk P., 2012 
keeping forces into the protection of common maritime domains 26 in border areas.

Third, inventory of positive experience and expertise of national military units, law enforcement agencies, international task forces, such as TIDES27ii, initiatives like CWS, and NGO is on preventing and containing non-traditional threats in the region. Local law-enforcement agencies, NGO'S and humanitarian task forces with their knowledge of social problems can transform the classical naval approach into a complex multi-lateral regional security initiative. 28

Forth, to create a technical model of a task force with "multi-purpose applicability" to the wide range of nontraditional. This cost effective model could be designed by joint Japanese, Chinese and American expertise on patrolling trade routes and disaster-relief operations.

\section{REFERENCES AND SELECT BIBLIOGRAPHY}

\section{List of related international treaties:}

Convention on the territorial sea and the contiguous zone, September 10, 1964

Convention on the prevention on maritime pollution by dumping of wastes and other matter, August 30, 1975

Convention for the suppression of unlawful acts against the safety of maritime navigation, march 10th, 1988

Niu Treaty on cooperation in fisheries surveillance and law enforcement in the South Pacific region may 20th, 1993 Regional cooperation agreement on combating piracy and armed robbery against ships in Asia, September 4, 2006 Convention on the high seas, September 30, 1962

Convention against transnational organized crime, September 29, 2003

Charter of the United Nations, October 24, 1945

United Nations Convention on the law of the sea, November 16th, 1994

\section{References from Journals:}

Dragici C., 2009. The development of self-contained regimes as an obstacle to UN global governance/International law in a multipolar world, International law association. Conference, Hull, England, p.-283

Halberstam, M., 1988, Terrorism on the high seas: The Achille Lauro, piracy and the IMO convention on maritime safety, 82 AJIL 269, p.273

Hoge, J., A global power shift in the making. 83 (4)

Foreign affairs 2-7

Keagle, J.M., 2012, Non-traditional security threats and
Asia Pacific regional cooperation/Centre for technology

And National security policy, NDU, 2012

Levive, N., 2013, in the straits of denial/JIS, V.22, \#2, fall 2013 Pareja-Alcaraz, P., 2009. International law and East Asia's regional order/International law in a multipolar world, International law association. Conference, Hull, England, p.-225 Miles K., 2000. Legalization as strategy: the case of Asia-Pacific. /International organization, 54 (3), pp. 549-571

Peppetti, J.D., 2008 Building the global maritime security network: a multi-national legal structure to combat transnational threats, 55 Naval Law Review pp. 73-78

Snidal, D., 1985. The limits of hegemonic stability theory/International organization, V.39, \#4

\section{References from Books:}

Alagappa, M., 2003, Asian Security order. Instrumental and normative features, Stanford University Press, California-628 p. Katzenshtein P., Shiraishi T., eds. Network power: Japan and Asia. Ithaca: Cornell University Press, 1997.

Klein N., 2011, Maritime security and the law of the sea, Oxford350p.

Leonard, E.K., 2005. The onset of global governance: the international relations theory and the evolution of the ICC.-237p. Marketos, T.N. 2009, China's energy geopolitics, Routledge Contemporary China series, Routledge, p.118

Rabasa, A., Chalk, P., 2012. Non-traditional threats and maritime domain awareness in the tri-border area of South-East Asia, RAND-NDRI-34 p.

\section{References from Other Literature:}

Erickson A., Collins G. a, 2012, China's real blue water navy/The Diplomat, August 30, 2012

Erickson A., Collins G. b, 2012 Near Seas Anti-navy' capabilities, not nascent blue water fleet, constitute China's core challenge to the US and regional militaries/China SignPost, March 6th, 2012

Multilateral Pact's key to security, 1999.Sunday Times, Singapore. May $23^{\text {rd, }}$ 1999. P.4

\section{References from websites:}

Indrajit, B., India the digital dumping ground/Asia Times online Homepage.

http://www.atimes.com/atimes/South_Asia/HH03Df01.html (October 27th, 2013)

Revised October 2013

${ }^{27}$ The Transformative Innovation for Development and Emergency Support program supports the basic needs of stressed populations by focusing on key infrastructure needs, building general capacities of civil authorities.

${ }^{28}$ Keagle, J.M, 2012

\footnotetext{
${ }^{26}$ As the UN Secretary General mentioned according to the Security Council Resolution 1674, not every breach of environmental law would necessarily constitute a threat to maritime security, but serious breaches may. Severe pollution of the maritime environment can be a result of intentional and unlawful damage to the environment and a flagrant violation of international environmental law.
} 